\title{
The Mythologeme "Coronavirus" in the Modern Mass Media News in Europe and Asia
}

\author{
Irina S. Karabulatovaa,c, Margarita D. Lagutkina ${ }^{a}$ \\ and Stefania Amiridou ${ }^{\text {b* }}$ \\ aPeople's Friendship University of Russia (RUDN University) \\ Moscow, Russian Federation \\ ${ }^{b}$ Democritus University of Thrace \\ Komotini, Greece \\ ${ }^{c}$ Moscow Institute of Physics and Technology \\ Machine Intelligence Laboratory \\ Moscow, Russian Federation
}

Received 02.02.2021, received in revised form 08.02.2021, accepted 09.04.2021

\begin{abstract}
The article analyzes the impact of nominations in the media discourse on the coronavirus on the public consciousness of Europe and Asia. The authors consider the historical, sociological, and psycholinguistic aspects of the use of names in texts about the coronavirus, identify the features of the impact of such texts on the reader and determine the target orientation of such texts. Hypothesis: names in news reports about coronavirus in modern news discourse in conditions of quarantine and self-isolation act as triggers that unite different strata of society, creating a hologram of a single mental space, actualizing archetypal images of the confrontation between Good and Evil. Particular attention is paid to the connection between ethno-confessional myths and ideas about the coronavirus in the public consciousness, their involvement in information wars. The methodology for the analysis of names is standard; it includes sociolinguistic, structural, and semantic analysis, evaluative, motivational, target analysis, etc. The study helps to understand linguistic universals in the transmission of psycho-emotional moods in a stressful situation in a pandemic. The article will be of interest to specialists in the field of linguistics, sociology, political science, psychology.
\end{abstract}

Keywords: proper name, news discourse, polycode, coronavirus, psycholinguistics, sociolinguistics, Russians, Albanians, Tatars, French, potential danger.

This paper was financially supported by the Ministry of Education and Science of Russian Federation on the program to improve the competitiveness of Peoples' Friendship University of Russia (PFUR University, RUDN University) among the world's leading research and education centers.

\footnotetext{
(C) Siberian Federal University. All rights reserved

* Corresponding author E-mail address: Karabulatova-is@rudn.ru, 2lagutkina_md@rudn.university, 3stefibless@hotmail.com ORCID: 0000-0002-4228-3235 (Karabulatova); 0000-0003-2830-6274 (Lagutkina); 0000-0002-1350-6807 (Amiridou)
} 
Research area: philology.

Citation: Karabulatova, I.S., Lagutkina, M.D., Amiridou, S. (2021). The mythologeme "coronavirus" in the modern mass media news in Europe and Asia. J. Sib. Fed. Univ. Humanit. Soc. Sci., 14(4), 558-567. DOI: $10.17516 / 1997-1370-0742$.

\title{
Мифологема «коронавирус» \\ в современных новостях масс-медиа Европы и Азии
}

\author{
И.С. Карабулатова а, , М.Д. Лагуткинаа, С. Амиридуб \\ ${ }^{a}$ Российский университет дружбы народов (РУДН) \\ Российская Федераџия, Москва \\ ${ }^{\sigma}$ Фракийский университет имени Демокрита \\ Греция, Комотини \\ ${ }^{8}$ Московский физико-технический институт \\ Лаборатория машинного интеллекта \\ Российская Федерачия, Москва
}

\begin{abstract}
Аннотация. В статье анализируется влияние номинаций в медиадискурсе на коронавирус на общественное сознание Европы и Азии. Авторы рассматривают исторические, социологические и психолингвистические аспекты использования имен в текстах о коронавирусе, выявляют особенности воздействия таких текстов на читателя и определяют их целевую направленность. Гипотеза: имена в новостных репортажах о коронавирусе в современном новостном дискурсе в условиях карантина и самоизоляции выступают в роли триггеров, объединяющих разные слои общества, создавая голограмму единого ментального пространства, актуализируя архетипические образы противостояния Добра и Зла. Особое внимание уделяется связи этноконфессиональных мифов и представлений о коронавирусе в общественном сознании, их вовлеченности в информационные войны. Методика анализа имен стандартная, включает социолингвистический, структурный и семантический анализ, оценочный, мотивационный, целевой анализ и т. д. Исследование помогает понять языковые универсалии в передаче психоэмоциональных настроений в стрессовой ситуации в условиях пандемии. Статья представляет интерес для специалистов в области лингвистики, социологии, политологии, психологии.
\end{abstract}

Ключевые слова: имя собственное, новостной дискурс, поликод, коронавирус, психолингвистика, социолингвистика, русские, албанцы, татары, французы, потенциальная опасность.

Работа выполнена при финансовой поддержке Министерства образования и науки Российской Федерации по программе повышения конкурентоспособности Российского университета дружбы народов (РУДН, РУДН) среди ведущих мировых научнообразовательных центров.

Научная специальность: 10.00.00 - филологические науки. 


\section{Introduction}

Humanity has not faced such large-scale problems for a long time as the modern pandemic of the coronavirus COVID-19. The modern pandemic activates forgotten archetypes and mythologemes in the public consciousness, which are characterized by an anthropomorphic image of the disease, which acts as an equalizer of the established socio-stereotypes of human civilization. Based on this, the coronavirus pandemic in modern media is portrayed as a war with some living / or like living beings opposing people.

Recently, apocalyptic sentiments are being heard more and more often in various mass media, while nominatives (proper names) appear in several guises, being in a clear dependence on the author's strategies and goals of speech behavior when writing texts about coronavirus. The restructuring of public consciousness is proceeding through the so-called "Overton windows" (Karabulatova, Savchuk, 2019) by using the polycode character of mythologemes that actualize the archetype of Death, referring each person to the image of the coronavirus as a symbol of the Apocalypse before the End of the World.

In this regard, we see references to the popular picture of the world of different peoples, including different religions, so we took in our study the idea of coronavirus in comparison with the mythology of Russian Orthodox, Greek Orthodox, Muslim Tatars, French Catholics, Albanians (Muslim and Christians) and Chinese Buddhists. This gives us insight into why fears and social deviations are on the rise in society due to the coronavirus. It is believed that Albanian culture remains one of the most incomprehensible and difficult to analyze due to the fact that most of the related languages have become extinct. In addition, Albanian norms of etiquette are rather vague, since Albanians can profess both Orthodoxy, Catholicism, and Islam. Based on this mutual nature of the Albanian mentality, we took for comparison Russians and Greeks as bearers of Orthodox culture, French as bearers of Catholicism, Tatars as bearers of Islam, Chinese as bearers of Buddhism and a representative of the "zero patient nation" in the coronavi- rus pandemic. Such a comparison gives us an understanding of the specific and universal in modern myths about coronavirus in different ethno-linguo-confessional environments.

The problem of analyzing nominatives in the mass-media discourse about coronavirus is that researchers perceive the metaphors used as "the final product of linguistic analysis, and there is no semantic motivation for why a particular metaphor is associated with a particular emotion. There is no linguistic, semantic link between physical motivation and the metaphor itself." (Apresyan, 1995: 456).

The disease has the character of stigma in any community (Bovina, Yakushenko, 2015). This attitude, according to N. Morant (2006), began to change in Western Europe in the second half of the twentieth century, however, the situation of the coronavirus pandemic began to be used as a powerful manipulative tool of modern information war (Barabash et al., 2019; Bernatskaya et al., 2020; Skovorodnikov et al., 2019) at a new stage of the digital format, when it is difficult for a layman to distinguish the truth from the fake. In this regard, there is an urgent need to develop tools for countering explicit and hidden manipuloms in the management of public consciousness. We propose to consider manipulative strategies used to change the picture of the world of recipients under manipulative methods. Manipuloms are based on cognitive modeling (Evseeva, Ponomareva, 2018). We propose the term manipuloma as a designation for manipulative techniques.

\section{Materials and Methods}

The discourse analysis of the news mass-media discourse about the coronavirus pandemic using nominatives considers, first, the principle of representativeness. This is a basic approach in sociolinguistics, which allows you to approach the description of the macrostructure of names that have signs of polycode, with subsequent interpretation depending on the communication tasks.

The targeted nature of the submission of materials in the Internet space allows you to quickly compare statistical data on publications about the COVID-19 pandemic in different countries, regions, cities, localities, etc. 
(Statistics of the spread of coronavirus in Russia for today, 24.10.2020).

In addition to sociolinguistic methods, we use the well-established methodology of traditional linguistics, linguoculturology, and psychology.

Thus, we determine the frequency characteristics of polycode names in the modern mass-media discourse about the coronavirus pandemic through descriptive statistics.

\section{Review and Discssion}

Sociology separately considers such a tool for manipulating public consciousness as rumors, gossip or the so-called "word of mouth", we can easily find their trace in the Internet space (for example, Yandex.Zen, social networks) (Osetrova, 2011).

Thus, it is the virtual image of the country formed in the mass media that is constructed using nominative markers, accumulating around itself news texts with proper names that ensure the reality of a particular phenomenon / event / place / person / society (Pocheptsov, 2015).

At the same time, the mass media discourse functions to ensure the fulfillment of the tasks of informativeness, suggestion, agitation, and propaganda (Chomsky, 2011; Zheltukhina, 2003), where the "assembly points" of the reliability of the proposed news are proper names. Any information indicating the name of the hero, the place of his location, etc. is designed to give the information guide features of authenticity and increase the attention of society, so proper names are experiencing a new flourishing in the situation of constructing realities in the virtual space of mass media. So, for example, the fake news constructed by professionals about the allegedly fallen meteorite in the Moscow suburb of Barybino on June 22, 2017, aimed at drawing public attention to the predatory seizure of land. High-quality fake content attracted the attention of the world media to the problem of Barybino residents and allowed to solve the problem of confrontation over the seizure of land by the "Coalco" company in favor of the village residents (Matveychev, 2017). A clear geographical reference, the involvement of experts in the field of mathematics, astronomy, physics helped to attract the attention of journalists from all over the world, while high-quality video and photo materials only supported the false news. At the same time, socially significant content about the coronavirus is replete with social potential dangers that form social schizophrenic reactions in society, which allowed I.S. Karabulatova to pose the problem of automatic evaluation of potentially dangerous texts in modern news discourse (2020). At the same time, the pragmatics of nominatives in the digital space of mass media discourse comes to the fore: the analysis of electronic communications is carried out in various aspects (Bernatskaya et al., 2020; Chudinov et al., 2019; Karabulatova, 2020)

\section{Results}

We believe that the mythologization of the coronavirus is influenced by the following classes of onyms:

1) anthroponyms, names of people (Ivan popular Russian male name; Henry is a French male name; Hanif - popular men's Tatar name; Arbery - a famous Albanian female name, etc.).

2) theonomy - the names of the deities (Bokura - a female deity of the Albanians, the person of the mother of all things; of Perun the Supreme male deity of the ancient Slavs, the God of Sky and lightning; Su Anasy - the Mother-Water is a in the Tatar mythology; Anku in French mythology, the deity of Death in women; Nuwa - in Chinese mythology, a female deity).

3) mythonyms - names of a fictional object/ subject (Alatyr - stone-the center of the universe in Russian mythology; Albasty - in Tatar mythology, a malevolent spirit, akin to the Russian Baba Yaga; Vuivr - a dragon-like creature, a hybrid of an Echid and a Wyvern in French culture; Kuchedra - a fire - breathing dragon with nine languages, sometimes turning into a shaggy woman with saggy breasts, Albanian folklore); Dzami - Evil demons in Chinese culture, seeking to harm people.

4) geopolitonyms - names of countries and regions (Russia, Siberia, Tatarstan, Albania, Berat, France, Brittany). 
5) mythopathonyms - folk names of diseases (tryasovitsa - fever in Rus.).

6) toponyms - names of geographical objects (Moscow, Paris, Kazan, Peshkopia, Shangrila).

7) informonyms - names of various media (newspapers, magazines, Internet channels, blogs, etc.), etc.

Folklorists have designated by the term mythopatonyme folk names of diseases and their symptoms. They believe that the disease acquires anthropomorphic features and is personified in the folk mythological picture of the world. The disease acts as a punitive tool of the higher powers for ordinary mortals, who are punished for their sins (Ivanova, 2015; Vystropova, 2019). At the same time, the names of diseases and symptoms of diseases occupy a key place in the sacred and ritual discourse of medicine practice both in the past and present, actualizing the archetype of disease as a transitional sign from the real world of health and life to the other world of death in the modern mythologized picture of the human world (Fang Xiang, 2017; Marinenko et al., 2019).

In this vein, new works on the analysis of the coronavirus problem in mass media and news discourses began to appear (Kisel, 2020; Karabulatova, Shekhi, 2020; Gornostayeva, 2020).

The situation of emotional blackmail and intimidation leads to the actualization of protest forms of public behavior, which makes it possible to classify such publications as potentially dangerous texts. Usually, emotional, and psychological anomalies are in "sleep mode", and a very powerful, constantly acting stimulus is necessary for their activation. The space of emotional and psychological anomalies itself

Table 1. Target orientation of the use of nominatives in the mass media discourse on the COVID-19 coronavirus

\begin{tabular}{|c|c|c|}
\hline $\mathrm{N} / \mathrm{n}$ & $\begin{array}{l}\text { Purpose of text } \\
\text { with nominative }\end{array}$ & $\begin{array}{l}\text { Examples of titles of publications in the media } \\
\text { (from open sources on the Internet) }\end{array}$ \\
\hline 1 & $\begin{array}{l}\text { Popular science attribu- } \\
\text { tion, } \\
\text { Clarification of the nature } \\
\text { of the coronavirus }\end{array}$ & $\begin{array}{l}\text { 1) Coronaviruses (Coronaviridae) are a fairly large list of viruses that can } \\
\text { infect both animals and humans, causing respiratory syndromes of varying } \\
\text { complexity. Belong to the II group of pathogenicity; } \\
\text { 2) Coronaviruses (Coronaviridae, CoV) - a family of viral infections from } \\
\text { the order of Nidovirales, which have the property of infecting not only hu- } \\
\text { mans, but also many different animals, especially pets, livestock, pigs and } \\
\text { others. As of } 2020 \text {, the coronavirus family includes } 40 \text { types of viruses. The } \\
\text { most popular of which, at least among people, was the virus "2019-nCoV" } \\
\text { (Wuhan coronavirus, Wuhan seafood market pneumonia virus) newly de- } \\
\text { tected at the end of } 2019 \text { in Wuhan (China), etc. }\end{array}$ \\
\hline 2 & Locus indication & $\begin{array}{l}\text { 1) For the first time, the coronavirus was recorded in Wuhan; } \\
\text { 2) The spread of coronavirus in Moscow is growing; } \\
\text { 3) Tighter coronavirus restrictions in Albania; } \\
\text { 4) In France, they announced the loss of control over the situation with coro- } \\
\text { navirus, etc. }\end{array}$ \\
\hline 3 & $\begin{array}{l}\text { An indication of a spe- } \\
\text { cific person (expert, etc.) } \\
\text { associated in one way or } \\
\text { another with the corona- } \\
\text { virus }\end{array}$ & $\begin{array}{l}\text { 1) Moscow Mayor Sergei Sobyanin announced measures to prevent coro- } \\
\text { navirus; } \\
\text { 2) Albania's Minister of Health Ogerta Manastiliu announced on October } 11 \\
\text { that the government had decided to introduce mandatory wearing of masks; } \\
\text { 3) The head of the scientific council under the French government, Jean-Fran- } \\
\text { cois Delfressy, called the situation with the coronavirus in the country crit- } \\
\text { ical; } \\
\text { 4) Prime Minister of Tatarstan Pesoshin commented on the increase in the } \\
\text { incidence of coronavirus in Tatarstan; } \\
\text { 5) Alexander Lukashev, a virologist, director of the Institute of Medical Par- } \\
\text { asitology at Sechenov University, allowed the third wave of coronavirus in } \\
\text { Russian regions, etc. }\end{array}$ \\
\hline
\end{tabular}


Continued Table 1

\begin{tabular}{|c|c|c|}
\hline $\mathrm{N} / \mathrm{n}$ & $\begin{array}{l}\text { Purpose of text } \\
\text { with nominative }\end{array}$ & $\begin{array}{l}\text { Examples of titles of publications in the media } \\
\text { (from open sources on the Internet) }\end{array}$ \\
\hline 4 & $\begin{array}{l}\text { Actualization of arche- } \\
\text { typal images and fears of } \\
\text { the unconscious }\end{array}$ & $\begin{array}{l}\text { 1) Fear of the coronavirus COVID-19; } \\
\text { 2) Coronavirus and the Phoenix bird archetype, the language of images and } \\
\text { symbols. Medical history and recovery; } \\
\text { 3) Russian biologists have discovered an ominous property of the corona- } \\
\text { virus; } \\
\text { 4) The coronavirus has become a harbinger of the apocalypse: the world is } \\
\text { on the brink of a global catastrophe; } \\
\text { 5) Coronavirus - Horseman of the Apocalypse; } \\
\text { 6) Could a zombie apocalypse start due to a virus in China? } \\
\text { 7) Deadly danger; } \\
\text { 8) The terrible forecast of scientists: } 80 \% \text { of humanity will die from the coro- } \\
\text { navirus; } \\
\text { 9) Experts told where the coronavirus lives. He is everywhere; } \\
\text { 10) Five minutes and everyone dies. The doctor told the truth about the coro- } \\
\text { navirus; } \\
\text { 11) The Dalai Lama Reveals the Secret Of COVID-19 To the World }\end{array}$ \\
\hline 5 & $\begin{array}{l}\text { Elimination of panic in } \\
\text { society }\end{array}$ & $\begin{array}{l}\text { 1) Panic moods due to the spread of coronavirus are based more on emotions } \\
\text { (perhaps artificially or generally for the sake of hype kindled) than on facts: } \\
\text { Professor of the St. Petersburg Research Institute of Experimental Medicine } \\
\text { Larisa Rudenko; } \\
\text { 2) Epidemic of mythology: is the coronavirus as terrible as it is portrayed; } \\
\text { 3) Virus with a legend. Which of the written about the coronavirus is true? } \\
\text { 4) "They don't believe in conspiracy theories": why the coronavirus disap- } \\
\text { peared in China }\end{array}$ \\
\hline 6 & $\begin{array}{l}\text { Leveling negative emo- } \\
\text { tions in society }\end{array}$ & $\begin{array}{l}\text { 1) Folk legends about the Covid-19 coronavirus; } \\
\text { 2) Conflict and stress due to uncertainty: how to cope with problems remote- } \\
\text { ly during a pandemic; } \\
\text { 3) Wait: a weak point of the coronavirus was found; } \\
\text { 4) A COVID-19 cough recognition system may appear at Russian airports; } \\
\text { 5) Former military medic A. Lytvyn says that the pandemic will be replaced } \\
\text { by a new Renaissance }\end{array}$ \\
\hline 7 & Constructing new myths & $\begin{array}{l}\text { 1) The main prophecy of Vanga - Russia will cope with the terrible virus; } \\
\text { 2) Forget it immediately: TOP } 6 \text { myths about coronavirus; } \\
\text { 3) The immunologist named ways of personal protection against coronavi- } \\
\text { rus; } \\
\text { 4) Coronavirus: } 5 \text { reasons to be optimistic; } \\
\text { 5) Coronavirus: instructions for survival; } \\
\text { 6) New solutions of the era of coronavirus, which we could not imagine some } \\
\text { six months ago }\end{array}$ \\
\hline 8 & $\begin{array}{l}\text { Laughing fear of corona- } \\
\text { virus, using humor }\end{array}$ & $\begin{array}{l}\text { 1) The Ministry of Health and Virologists have dispelled popular myths } \\
\text { about the coronavirus. Immunity in smokers and "no more dangerous than } \\
\text { the flu": top } 10 \text { autumn myths about coronavirus; } \\
\text { 2)Alcohol and a bath will not help: doctors have denied the most popular } \\
\text { myths about the coronavirus; } \\
\text { 3) } 40 \text { selected jokes about coronavirus in order not to fall into despair; } \\
\text { 4) Before Halloween, Russians began to buy a coronavirus costume; } \\
\text { 5) Defeat the coronavirus like the Pechenegs; } \\
\text { 6) } 25 \text { original ways to have fun in quarantine; } \\
\text { 7) Folk creativity for self-isolation: coronavirus, go away, you are not wel- } \\
\text { come here; } \\
\text { 8) How the coronavirus changed porn. Yes, this world won't be the same }\end{array}$ \\
\hline
\end{tabular}


contains many various neuropsychiatric abnormalities that differ in etiology, anamnesis, and clinical picture (Bernatskaya et al., 2020; Karabulatova, 2020). The more severe the personality disorders, the more difficult it is for such a person to critically perceive the information. Hence, we see the growth of publications that appeal to the mythologized picture of the world, fairy tales, beliefs, legends (Fang Xiang, 2017).

Simplifications in the personal picture of the world lead to cognitive distortions based on various classes of logical disorders, which, in turn, is predetermined by differences in the volume of background knowledge, differentiation of the volume of concepts in RAM, as well as in the choice of stereotypes of strategies for presenting material to the audience.
At the same time, disorders in the emotional and mental sphere are characterized by an unstable balance between the norm and pathology, so these anomalies belong to the borderline level of mental disorders.

Potentially dangerous texts about the coronavirus can be shown in the form of the "Overton window" (Fig. 1) scheme, which will clearly demonstrate the progressive "pressure steps" on the human psyche in the context of a shift from the social norm to deviations and to more serious psychopathology.

We believe that such powerful epidemics and pandemics (Marinenko et al., 2019) as the COVID-29 coronavirus pandemic actualize popular beliefs that live in the realm of the unconscious. The mythopathonym "coronavirus COVID-19" itself focuses on such archetyp-

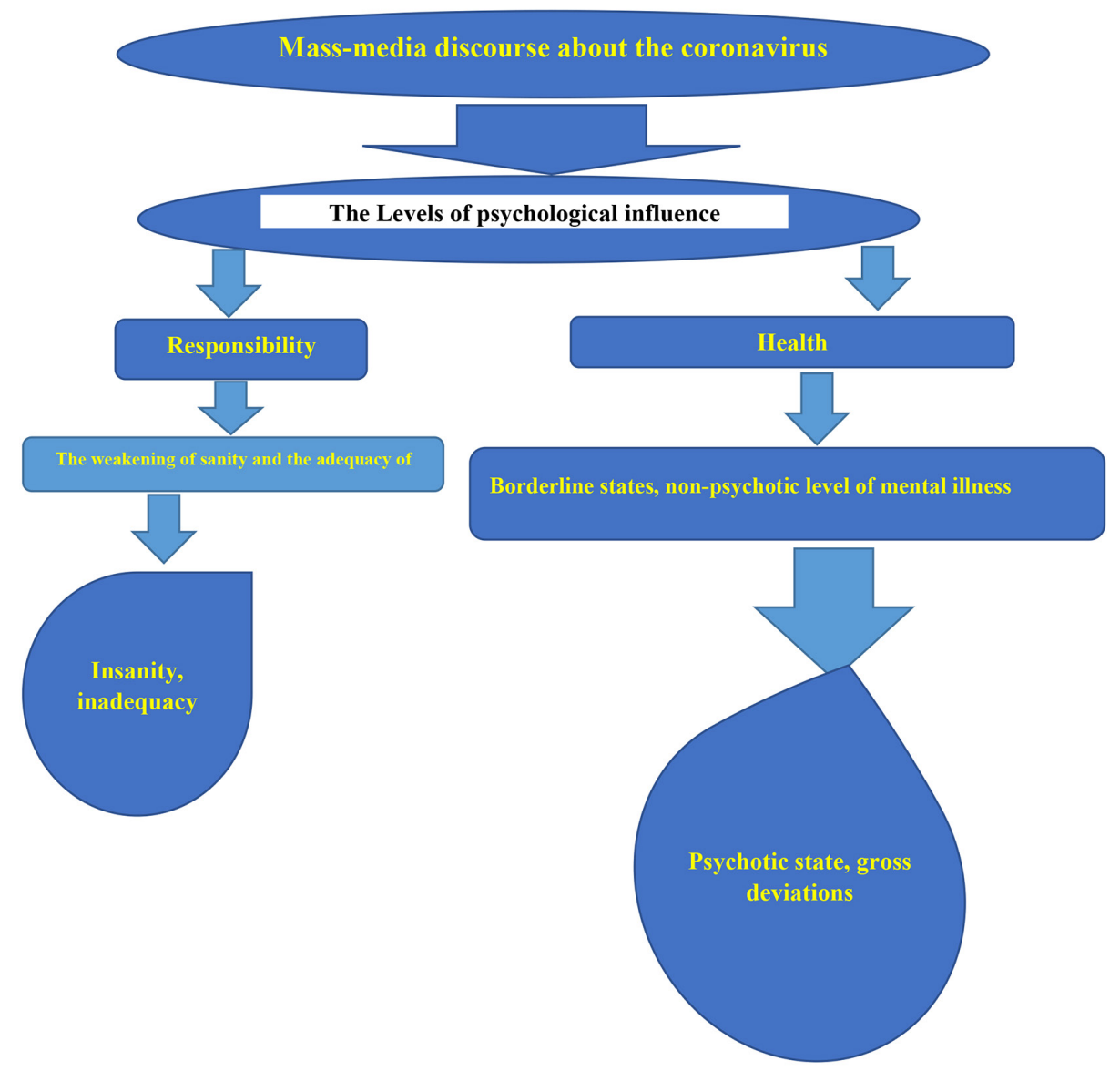

Fig. 1. "Overton Window": "Pressing steps" of the mass-media discourse on the coronavirus, transforming the preservation of the psyche in the context of psychopathology 
al fears as the fear of death, the prediction of the Apocalypse, the death of all living things, the death of humanity, the end of the world, obsession with devilish forces, heavenly punishment. At the same time, the mythologeme coronavirus actualizes the mythologeme about the sacred significance of Russia (Karabulatova, Shehi, 2020).

Ideas about the coronavirus fit perfectly into the mythology of the disease in the picture of the human world. The very type of pathogen, designated as a coronavirus, actualizes the anthropomorphism of COVID-19. The designation in everyday speech, as simply a crown, indicates the opposition of the male and female worlds, since in the mythologized picture of the world, the disease, as a rule, is designated by a female name or has a female gender. For example, in the Slavic languages: tryasovitsa, fever, erysipelas, scrofula, rubella, dropsy, sternum, etc.

In almost all languages, the disease is indicated in the form of a woman. So, in the Albanian language, which is a separate group among the Indo-European languages, there is the concept of a Strigoi, i.e. an evil witch who drinks blood at night, as a result of which a person becomes seriously ill. This character, according to the beliefs of the Albanians, eats human flesh. Also manifests itself and Lamaya (Llamaja), which appears in the form of a woman with a snake's tail and eats people.

Traditionally, diseases, especially those caused by viruses and infections, have been imprinted in the popular memory of the peoples of the world as a tool of blind, thoughtless, and ruthless force with a huge number of victims. Therefore, we see in the Albanian, Russian, and Tatar mythology the designations of numerous spirits who punish people who stumble with diseases, acting as a payment for sins.

So, in Tatar mythology there is a female image of the evil Albasty, which suffocates a person, causes cough, asthma, pulmonary edema, leading to the death of a person. To cure the patient and remove the fear of the disease and, consequently, before death, it is necessary to identify the disease, so the disease as a manifestation of the forces of Evil in the Tatar folk picture of the world is associated with the influence on a person of such mythical images as Yale, Shaitan, Chin-Sekmet, which are rooted in the pre-Islamic beliefs of the Tatars, and the so-called "popular Islam". As a rule, the symptoms are personified, each feature is described metaphorically and anthropomorphically, which is generally characteristic of the folk picture of the world and the mythologized consciousness of the native speaker.

In the Albanian mythological picture of the world, a special place is occupied by the personified Eternal Femininity, which acts as E Bukuri e Dheut (E Bukuri e Dheut) or the so-called Beauty of the Earth, i.e., the most beautiful woman of mankind, which is a symbol of happiness, well-being, health, and prosperity (Karabulatova, Shehi, 2020). Bucuri is portrayed as a golden-haired, white-skinned beautiful woman. In Albanian anthroponymy, Bukuri has become one of the most popular female names. At the same time, if the balance of Good and Evil is broken, then Bukuri can act on the side of the dark forces, then she turns into a black, black-haired woman, bringing disease, grief, desolation. Therefore, in the situation with the pandemic in Albania, they began to say: "Beautiful as Bukuri, but the crown hinders". Here we see the combination of the values of corona: 1) a symbol of universally recognized beauty, 2) arrogance and pride, 3) the designation of the coronavirus (Shehi et al., 2020).

At the same time, we see the mythologization of protective and preventive measures for the spread of diseases. So, in the national picture of the world common belief that there are places where people live and spirits of disease, and if you get in a place (in other words, the center of disease), the disease settles forever in the soul and the body, leading to his death. The virus and infection are designated as bad air, unclean air, which emphasizes the nature of the spread of such diseases.

An indication of the original source of this disease - bats, an image that is endowed with an initially negative connotation in different linguistic and cultural worlds, also contributes to the strengthening of the coronavirus mythologeme. It is enough to remember that in European culture, the forces of Evil can turn into bats. 
The bat is an accomplice of witches, sorcerers. The bat is one of the symbols of vampires and other evil spirits. In ancient times, it was believed that the soul of a deceased person can fly in the form of a bat. Some publications indicate caves where bats live. In some publications, coal mines were indicated, which increased the negative impact on humans, contributing to an even stronger mythologization of the coronavirus. At the same time, two opposing points of view came into opposition: the bat - a symbol of Evil (European mythologeme), and the bat - a symbol of happiness and well-being (Chinese mythologeme). But in most mythologies, the bat is either a personification of the forces of Evil, or a talisman from the forces of Evil, which activates the associative space of the concept of "bat" in the language culture.

\section{Conclusion}

The personification of diseases through the designation through the work of certain evil spirits, helps to cope with the uncontrolled fear of death, performing the psychotherapeutic role of maintaining mental health in a stressful situation. Diseases, especially epidemics and pandemics, in folk mythology appear as the result of the work of certain demonic entities that are similar in some ways to people but are opposed to the human world.

In this situation, the lack of consideration of the features of the mythologized picture of the world of modern man in news texts about the coronavirus leads to an unconscious strengthening of one of the negative components of the polycode message about the coronavirus, which carries the possibility of using the "window of discourse" in the context of the formation of a potential danger to society.

Today, news stories about coronavirus are at the top of the list worldwide. The reason for most of our fears is imagination, which fills the missing gaps with the background knowledge of the ethnic group about similar situations.

\section{References}

Apresyan, Yu.D. (1995). Integral'noye opisaniye yazyka i sistemnaya leksikologiya [Integral description of language and systematic lexicology]. In Izbrannyye raboty: $v 2 \mathrm{tt}$. [Selected works: in 2 vols.]. M., 2.

Barabash, V.V., Kotelenets, E. A., Karabulatova, I.S., Lavrentyeva, M.Yu., Mitina, Yu.S. (2019). The confrontation between the Eastern and Western worldviews in the conceptual space of the information war against Russia: the genesis and evolution of the terminological apparatus. In Amazonia investiga, 8 (19), 246-254.

Bernatskaya, A.A., Gornostaeva, E.A., Evseeva, I.V., Zhuneva, E.S., Zaripov, R.I., Ivanova, E.A., Kirilina, A.V., Kolmogorova, A.V., Kopnina, G A.A., Kushneruk, S.L., Lupanova, E.V., Mikhailyukova, N.V., Panova, Yu.V., Prilukova, E.G., Romanov, A.S., Sabirov, V.Sh., Samkova, M.A., Skovorodnikov. A.P., Soina. O.S., Chudinov. S.I. and other (2020). Lingvistika informatsionno-psikhologicheskoi voiny [Linguistics of information and psychological warfare]. Krasnoyarsk: Siberian Federal University, III.

Chudinov, A.P., Koshkarova, N.N., Ruzhentseva, N.B. (2019). Lingvisticheskaia interpretatsiia rossiiskoi politiki cherez prizmu feika, dipfeika, postpravdy [Linguistic interpretation of Russian policy through the prism of fake, deepfake, post-truth]. In Journal of the Siberian Federal University. Series: Humanities, $12,10,1840-1853$.

Gornostayeva, Yu.A. (2020). Leksicheskiye sredstva diskursivnogo konstruirovaniia obraza V. Putina $\mathrm{v}$ ispanskikh amerikanskikh i amerikanskikh SMI v aspekte pandemii koronavirusa [Lexical means of discursive construction of the image of V. Putin in the Spanish American and American media in the aspect of the coronavirus pandemic]. In Filologicheskiye nauki. Voprosy teorii i praktiki [Philological sciences. Questions of theory and practice]. Tambov: Gramota, 13 (9), 246-250

Evseeva, I.V., Ponomareva, E.A. (2018). Leksiko-slovoobrazovatel'noye gnezdo: kognitivnoye modelirovaniye [Lexico-word-formation nest: cognitive modeling], Krasnoyarsk, Sibirskiy federal'nyy universitet [Siberian Federal University], 199.

Fang Xiang (2017). Features of disease nomination in English, Russian and Chinese. In J. Belarus. State Univ. Philol., 1, 106-111. 
Ivanova, V.V. (2015). Imena sobstvennyye v narodnykh nazvaniiakh boleznei v chuvashskom iazyke [Proper names in folk names of diseases in the Chuvash language]. In Nauchnyye issledovaniia: ot teorii $k$ praktike [Scientific research: from theory to practice], 2, 4 (5), 124-128.

Karabulatova, I.S., Savchuk, I.P. (2019). Transformatsionnaia evoliutsiya gendera v sovremennom reklamnom diskurse kak proiavleniye "Okna Overtona" [The transformational evolution of gender in modern advertising discourse as a manifestation of the "Overton Window"]. In Izvestiia Baltiiskoy akademii rybopromyslovogo flota: psikhologo-pedagogicheskiye nauki [Proceedings of the Baltic Academy of Fishing Fleet: Psychological and pedagogical sciences], 2 (48), 23-32.

Karabulatova, I. (2020). Possibilities of artificial intelligence in assessing the impact of potentially dangerous texts in modern news discourse: problem of statement. In International Scientific Forum "Issues of Modern Linguistics and the Study of Foreign Languages in the Era of Artificial Intelligence (dedicated to World Science Day for Peace and Development)" (LLT Forum 2020), Published online: 24 December 2020, 88, https://doi.org/10.1051/shsconf/20208801001

Karabulatova, I.S., Shehi, E. (2020). Vliianiye imen sobstvennykh na transformatsiiu arkhetipicheskikh predstavleniy o koronaviruse v sovremennoy mifologizirovannoy kartine mira. In Vestnik Adygeyskogo gosudarstvennogo universiteta. Seriia Filologiia i iskusstvovedeniye [Bulletin of the Adyghe State University. Series Philology and Art History], 4 (267), 54-61.

Kisel, I.F. (2020). Metaforicheskaia reprezentatsiia poniatiia "koronavirus" v mediadiskurse (na materiale russkogo i nemetskogo iazykov) [Metaphorical representation of the concept of "coronavirus" in the media discourse (based on the material of the Russian and German languages)]. In Vestnik Adygeyskogo gosudarstvennogo universiteta. Seriia: Filologiia i iskusstvovedeniye [Bulletin of the Adygeya State University. Series: Philology and Art History], 4 (267), 62-67.

Marinenko, L.E., Kattsina, T.A., Karabulatova, I.S., Mezit, L.E. (2019). Istoricheskiy opyt bor'by s epidemiiami v Yeniseiskoy gubernii v kontse XIX - nachale XX vv. [Historical experience of combating epidemics in the Yenisei province in the late 19th - early 20th centuries]. In Bylye Gody, 54, 4, 1737-1744. DOI: $10.13187 /$ bg.2019.4.1737.

Matveychev, O. (2017). Feykovyy meteorit spasayet ot zakhvata zemel' [A fake meteorite saves from land capture], from 02.07.2017 [Electronic resource]. Available at: https://matveychev-oleg.livejournal. com/5712841.html (date of base 20.20.2018).

Osetrova, E.V. (2019). Slukhi v sovremennoy kul'ture: istoriograficheskiy obzor [Rumors in modern culture: a historiographical review]. In Antropologicheskiy forum [Anthropological forum], 15-online, 5581.

Skovorodnikov, A.P., Kopnina, G.A., Kolmogorova, A.V. (2019). Information and Psychological War Linguistics as a research project at the Siberian Federal University: problems and achievements. In Journal of Siberian Federal University. Humanities and Social Sciences, 12, 10.S, 1904-1921.

Pocheptsov, G.G. (2015). Narrativnyye instrumenty vozdeistviia [Narrative tools of influence]. In Verkhnevolzhskiy filologicheskiy vestnik [Upper Volga Philological Bulletin], 3, 69-74.

Shehi, E., Karabulatova, I.S., Niyazova, G., Khuong Thi Thu Trang (2020). Polycode content of news texts about coronavirus with proper names (PN) in electronic socio-political discourse. In International Scientific Forum "Issues of Modern Linguistics and the Study of Foreign Languages in the Era of Artificial Intelligence (dedicated to World Science Day for Peace and Development)" (LLT Forum 2020). Published online: 24 December 2020, 88, https://doi.org/10.1051/shsconf/20208801028

Statistics of the spread of coronavirus in Russia for today, 24.10.2020 [Electronic resource]. Available at: https://coronavirus-monitor.info/country/russia/

Vystropova, O.S. (2019). Priznaki bolezni. Nominatsiia v shotlandskom dialekte [Signs of disease nomination in the Scots dialect]. In Filologicheskiye nauki. Voprosy teorii i praktiki [Philological sciences. Questions of theory and practice], 12, 1, 88-93.

Zheltukhina, M.R. (2003). Politicheskiy i massmedial'nyy diskursy: vozdeystviye - vospriyatiye - interpretatsiya [Political and mass media discourses: impact-perception-interpretation]. In Yazyk, soznaniye, kommunikatsiya [Language, consciousness, communication: collection of articles]. Moscow, 23, 38-51. 